\title{
Seroprevalence of Toxoplasma gondii in Sheep from Nevşehir Province in Turkey
}

Nevşehir Yöresi Koyunlarında Toxoplasma gondiỉ nin Seroprevalansı

\section{Dilek Özmutlu Çakmak¹, Bilge Karatepe}

'Department of Biology, Niğde Ömer Halisdemir University, Graduate School of Natural and Applied Sciences, Nigde, Turkey

${ }^{2}$ Niğde Ömer Halisdemir University, Bor Vocational School, Nigde, Turkey

Cite this article as: Özmutlu Çakmak D, Karatepe B. Seroprevalence of Toxoplasma gondii in Sheep from Nevşehir Province inTurkey. Türkiye Parazitol Derg 2017; 41: 148-51.

\section{ABSTRACT}

Objective: The goal of this study was to investigate the seroprevalence of Toxoplasma gondii (T. gondii) in sheep from Nevşehir Province in Turkey.

Methods: Blood samples were taken from 180 sheep aged between 1 and 7 years, which were randomly selected from seven different study sites in Nevşehir Province. The enzyme-linked immunosorbent assay (ELISA) for the detection of antibodies to T. gondii was performed on all the serum samples.

Results: Eighteen (10\%) serum samples were found to be seropositive for T. gondii antibodies. The highest seropositivity rate (11.53\%) was found in sheep aged between 1 and 2 years, whereas the lowest seropositivity rate (8.51\%) was found in sheep aged between 5 and 7 years old. Eighteen of the 162 ewes (11.1\%) were found to be seropositive, whereas none of the 18 tested rams were seropositive. In addition, considering the study site location, the highest seropositivity rate was in Avanos (32\%), whereas the lowest seropositivity rate was in Kozakli (2.9\%). The T. gondii seropositivity rates were statistically insignificant with regard to age groups and gender ( $p>0.05)$, whereas they were statistically significant $(p<0.05)$ with regard to study centers.

Conclusion: This is the first serological report on toxoplasmosis in sheep from Nevşehir Province in Turkey.

Keywords: Toxoplasma gondii, sheep, Nevşehir, seroprevalence, ELISA, Turkey

Received: 06.02.2017

Accepted: 02.08 .2017

Öz

Amaç: Bu çalışma, İç Anadolu Bölgesinde Nevşehir yöresinde bulunan koyunlarda Toxoplasma gondii (T. gondii)'nin seroprevalansının araştırılması amacı ile yapılmıştır.

Yöntemler: Çalışmanın materyali olarak Nevşehir ilinde 7 farklı çalışma merkezine ait (Gülşehir, Nevşehir Merkez, Kozaklı, Acıgöl, Avanos, Hacıbektaş, Derinkuyu) 1-7 yaş arasında toplam 180 koyun rastgele seçilerek kan örnekleri alınmıştır. Alınan kan örneklerinin serumları çıkarılmış T. gondii antikorları yönünden ELISA testi ile incelenmiştir.

Bulgular: Nevşehir yöresinde ELISA testi ile incelenen toplam 180 koyunun 18 (\%10)'inin T. gondii antikorları yönünden seropozitif olduğu tespit edilmiştir. Bunun yanında en yüksek seropozitiflik \%11,53 oranı ile 1-2 yaşındaki koyunlarda tespit edilirken en az seropozitiflik oranı ise \%8,51 ile 5-7 yas arası koyunlarda belirlenmiștir. Cinsiyetlere göre 162 koyunun $18(\% 11,1)^{\prime}$ inde seropozitiflik tespit edilmiş, buna karşılık 18 koçta seropozitiflik saptanmamıştır. Ayrıca çalışma merkezleri açısından koyunlarda en yüksek seropozitiflik \%32 oranı ile Avanos'da, en düşük seropozitiflik ise \%2,9 oranı ile Kozaklı'da tespit edilmiștir. Elde edilen seropozitiflik oranlarında; koyunların yaş grupları ve cinsiyetlerinin istatistiksel olarak önemli $(p>0,05)$ olmadığı, çalışma merkezlerinin ise istatistiksel olarak önemli olduğu saptanmıştır $(p<0,05)$.

Sonuç: Nevşehir yöresinde koyunlarda Toxoplasma gondii'nin varlığı ilk kez bu çalışma ile belirlenmiştir.

Anahtar Kelimeler: Toxoplasma gondii, koyun, Nevşehir, seroprevalans, ELISA, Türkiye

Geliş Tarihi: 06.02.2017

Kabul Tarihi: 02.08.2017

Address for Correspondence / Yazışma Adresi: Bilge Karatepe, E.mail: bkaratepe@ohu.edu.tr DOI: $10.5152 /$ tpd.2017.5245

(C) Copyright 2017 Turkish Society for Parasitology - Available online at www.tparazitolderg.org

(OTelif hakkı 2017 Türkiye Parazitoloji Derneği - Makale metnine www.tparazitolderg.org web sayfasından ulaşılabilir. 


\section{INTRODUCTION}

Toxoplasmosis is a zoonotic disease caused by the intracellular protozoan parasite T. gondii, and it may affect all mammals, humans, and birds (1-4). The definitive hosts for the T. gondii are cats and other felines, whereas the intermediate hosts are all the birds and mammals, including humans $(2,4-6)$.

Toxoplasmosis in sheep and other animals is subclinical. In some acute cases, toxoplasmosis may cause symptoms such as an increased body temperature, loss of appetite, diarrhea, lack of energy, and breathing problems. Those symptoms are generally not typical of the disease; therefore, the diagnosis of toxoplasmosis in sheep only by observing the symptoms is difficult. As with other organisms, the diagnosis of toxoplasmosis in living sheep can be achieved by various serological methods (1).

The Sabin-Feldman dye test (SFDT), indirect fluorescent antibody test (IFAT), indirect hemagglutination test (IHA), complement fixation test (CFT), and enzyme-linked immunosorbent assay (ELISA) are some of the various tests available to diagnose toxoplasmosis $(1,5,6)$.

Previous studies conducted in Turkey indicate that the average prevalence of toxoplasmosis in sheep is $40 \%$, with regional variations ranging between $2.8 \%$ and $95.7 \%$ (7-15).

The aim of this study was to determine the seroprevalence of $T$. gondii infection in sheep from Nevşehir Province in Turkey.

\section{METHODS}

\section{Study Area}

The material used in this study was the blood serum samples taken from randomly selected 180 sheep aged 1 to 7 years. This study included sheep from Nevşehir Province, located in the Central Anatolia Region, Turkey (with an altitude of $1260 \mathrm{~m}, 38^{\circ} 37^{\prime} \mathrm{N}$ longitude-34 $43^{\prime} \mathrm{E}$ latitude), where toxoplasmosis has not been previously detected. In the present study, Gulsehir, Nevşehir Central, Kozakli, Acigol, Avanos, Hacibektas, and Derinkuyu districts were chosen as study sites in Nevşehir Province. In Nevşehir, the annual average precipitation is $429.4 \mathrm{~kg} / \mathrm{m}^{3}$, the average temperature $10.6^{\circ} \mathrm{C}$, and the average relative humidity $60.6 \%$.

Blood samples were collected in a sterile tube from the punctured jugular vein of sheep. Serum samples were obtained by centrifugation at room temperature $\left(25^{\circ} \mathrm{C}\right)$, at $4000 \mathrm{rpm}$ for 10 minutes, and were stored at $-20^{\circ} \mathrm{C}$ until analyzed. To detect the T. gondii antibodies, CHEKIT-Toxotest ELISA Test Kit (IDEXX, AG,
Switzerland) was used in the study. The ELISA test was performed according to the instructions listed on the commercial kit.

\section{Reading and Calculation of Results}

The test was performed according to the procedure described by the manufacturer and the results were assessed at a wavelength of 450nm using an ELISA microplate reader (MR-96A). The following equation was used:

Value $\%=\underline{\text { O.D. sample-O.D. negative }} \quad \times 100$ O.D. positive-O.D. negative

If the test sample's percentage value was greater than or equal to $100 \%$, the test was considered to be positive. If the result was greater than or equal to $30 \%$ or less than $100 \%$, the test was weakly positive. If the result was greater than or equal to $20 \%$ and less than $30 \%$, the result was suspicious. Finally, if the result was less than $20 \%$, the test was considered to be negative.

\section{Statistical Analysis}

The chi-squared test was applied to compare the rate of seropositivity between age groups, gender, and study sites. Statistical significance in this study was defined as $p<0.05$.

\section{RESULTS}

Out of the 180 sheep aged between 1 and 7 years from seven different sites in Nevşehir Province, the ELISA test showed that 18 sheep (10.0\%) had anti-T. gondii antibodies.

According to Table 1, the highest seropositivity rate of $11.53 \%$ was detected in 1- to 2-year-old sheep, whereas the lowest seropositivity rate of $8.51 \%$ was detected in 5 - to 7 -year-old sheep. As a result, the seropositivity rate among the seropositive animals with regard to the age groups of the sheep was not statistically significant ( $p>0.05)$.

Table 1. Toxoplasma gondii seropositivity rate by ELISA in sheep with regard to age groups

\begin{tabular}{|l|c|c|c|}
\hline $\begin{array}{l}\text { Age } \\
\text { Groups }\end{array}$ & $\begin{array}{c}\text { Animals } \\
\text { Examined }\end{array}$ & $\begin{array}{c}\text { Positive } \\
\text { Animals }\end{array}$ & $\begin{array}{c}\text { Seropositivity } \\
\text { Rate (\%) }\end{array}$ \\
\hline $1-2$ & 78 & 9 & 11.53 \\
\hline $3-4$ & 55 & 5 & 9.09 \\
\hline $5-7$ & 47 & 4 & 8.51 \\
\hline Total & 180 & 18 & 10.0 \\
\hline
\end{tabular}

Table 2. Toxoplasma gondii seropositivity rate with regard to the study centers

\begin{tabular}{|c|c|c|c|c|}
\hline Study Site & Month & Animals Examined & Positive Animals & Seropositivity Rate (\%) \\
\hline Gulsehir & February & 38 & 2 & $5.3^{b}$ \\
\hline Centre & March & 23 & 2 & $8.7^{b}$ \\
\hline Kozakli & April & 34 & 1 & $2.9^{b}$ \\
\hline Acigol & May & 30 & 2 & $6.7^{b}$ \\
\hline Avanos & June & 25 & 8 & $32.0^{a}$ \\
\hline Hacibektas & July & 11 & 1 & $9.1^{b}$ \\
\hline Derinkuyu & August & 19 & 2 & $10.5^{b}$ \\
\hline TOTAL & & 180 & 18 & 10.0 \\
\hline
\end{tabular}


Table 2 shows the seropositivity rates in sheep according to the study sites. As the table indicates, the sheep in Avanos had the highest seropositivity rate (32.0\%), whereas the lowest seropositivity rate was in Kozakli (2.9\%). As a result, the seropositivity rate of $T$. gondii among the seropositive animals with regard to the study sites was determined to be statistically significant $(p<0.05)$. In addition, the presence of cats was confirmed at all study sites.

With regard to the gender groups, out of 162 ewes, 18 (11.1\%) were found to be seropositive, whereas no seropositivity was detected in the 18 rams tested. Seropositivity rates of the two gender groups were compared; the differences between the seropositive animals were not statistically significant ( $p>0.05)$. Out of the 8 sheep that miscarried, none were found to be seropositive.

\section{DISCUSSION}

In Turkey, the seroprevalence of toxoplasmosis in sheep was 20\%-39.28\% as indicated by CFT $(8,13), 36 \%$ by ToxHAtest commercial kit (16), $14.66 \%-37 \%$ by LAT $(9,17), 22.5 \%$ in gravid ewes, $30.97 \%$ in ewes by IHA $(12,18), 22 \%-95.7 \%$ by ELISA $(14,18)$, $28.04 \%-88.70 \%$ by SFDT $(7,9,10,13,19-23)$, and $13 \%-72 \%$ by IFAT $(9,24,25)$.

In our study, the seroprevalence of T. gondii was 10\% in sheep from Nevşehir in Turkey. This seropositivity rate of $10 \%$ is clearly lower than the seropositivity rates observed in other studies carried out in Turkey. The differences in the results from various studies can be attributed to various factors, such as geographic differences, various types of the serological tests employed, the type and number of sheep examined, and the number and density of the definitive host, cats. Moreover, the rate of seroprevalence in this study was similar to the results found in Konya (24).

The seroprevalence of anti-T. gondii antibodies in sheep has been reported in several countries. The T. gondii seropositivity was found to be $7.4 \%$ by IHAT, $9.2 \%$ by IgG-ELISA, and $25.2 \%$ by IgM-ELISA in Australia (26); $65.5 \%$ by MAT in USA (27); $13.9 \%$ in small flocks of sheep and $28.5 \%$ big flocks of sheep by LAT and IFAT in Uruguay (28); $2.5 \%$ by LAT in Pakistan (29); $24.50 \%$ by LAT and IHAT in Iran (30); $12 \%$ by IHAT and $28 \%$ by IIFT in Chile (31); $18.75 \%$ by LAT in Brazil (32); $3.6 \%$ by MAT in North America (33); $13.8 \%-74.5 \%$ in Syria (34); $28.4 \%$ by IgG-IFAT; $9 \%$ by IgM-IFAT and $11.1 \%$ PCR in Italy (35); $27.6 \%$ by IgG-ELISA in Morocco (36); $26.5 \%$ by IFAT in Iran (37); and $19.88 \%$ by ELISA and LAT in Pakistan (38).

The seropositivity rate of $10 \%$ detected in this study is lower than the seropositivity rates reported in other studies from different parts of the world $(27,28,30-32,34,36-38)$. On the other hand, the rates of $3.6 \%$ and $2.5 \%$ observed by Dubey and Foreyt in North America (33) and Zaki in Pakistan (29), respectively, are lower than the seropositivity rates observed in Nevşehir. These differences can be attributed to the differences in country of study, the type of the serological tests used, the differences in the sheep examined, and the number of the definitive hosts, cats. Moreover, the seropositivity rate of $10 \%$ observed in this study is similar to the rates found in Australia (9.2\%) and Italy $(9-11.1 \%)(26,35)$.

In the present study, although we found no differences in the T. gondii seroprevalence rates with regard to mean age among sheep ( $p>0.05)$, T. gondii antibodies in the 1-2-years age group were more common than in the 5-7-years age group. The difference was probably due to the presence of maternal antibodies or latent infection. In addition, other external factors, such as farm management or feeding behavior, could account for this discrepancy. Likewise, among the seropositive animals, statistical significance with regard to gender was not observed ( $p>0.05)$. However, the T. gondii seropositivity prevalence rate among the seropositive animals with regard to the location of study centers was found to be statistically significant $(p<0.05)$, where Avanos was identified as having the highest seropositivity rate (32.0\%), and Kozaklı the lowest seropositivity rate (2.9\%). The differences between the seropositivity rates in the study centers could be attributed to the breeding conditions, the population of the definitive host cats, and the level of contact those cats have with sheep feeders and waterers.

\section{CONCLUSION}

The study results clearly identify the presence of T. gondii in the sheep from Nevşehir Province in Turkey. Consequently, T. gondii should be considered a possible cause of miscarriage in sheep. Therefore, considering the fact that cats are the definitive hosts and one of the most important factors in the spread of the infection, they should be kept away from the sheep feeders and waterers, and pens and the pastures, thus preventing contamination through cat feces $(1,2,5)$. To determine the effects of toxoplasmosis on sheep breeding in Nevşehir, a larger study that would also investigate cats, the definitive hosts for T. gondii, is recommended.

Ethics Committee Approval: Authors declared that the research was conducted according to the principles of the World Medical Association Declaration of Helsinki "Ethical Principles for Medical Research Involving Human Subjects".

Informed Consent: Not required in this study.

Peer-review: Externally peer-reviewed.

Author Contributions: Concept - D.Ö.Ç., B.K..;Design - D.Ö.Ç., B.K.; Supervision - D.Ö.Ç., B.K.; Funding - D.Ö.Ç., B.K.; Materials - B.K.; Data Collection and/or Processing - D.Ö.Ç.; Analysis and/or Interpretation D.Ö.Ç., B.K.; Literature Review - D.Ö.Ç.; Writing - D.Ö.Ç., B.K.; Critical Review - B.K.; Other - D.Ö.Ç., B.K.

Acknowledgement: The authors would like to thank to Niğde Ömer Halisdemir University Scientific Research Projects Unit that supported our study.

Conflict of Interest: No conflict of interest was declared by the authors.

Financial Disclosure: This study is a summary of Dilek Özmutlu Çakmak's (first surname Öztürk) MSc thesis. This study was financially supported by Niğde Ömer Halisdemir University Scientific Research Projects Coordination Unit.

Etik Komite Onayı: Yazarlar çalışmanın World Medical Association Declaration of Helsinki "Ethical Principles for Medical Research Involving Human Subjects" prensiplerine uygun olarak yapıldığını beyan etmişlerdir.

Hasta Onamı: Bu çalışma için hasta onamına gerek yoktur. 
Hakem Değerlendirmesi: Dış bağımsız.

Yazar Katkıları: Fikir - D.Ö.Ç., B.K.; Tasarım - D.Ö.Ç., B.K.; Denetleme D.Ö.Ç., B.K.; Veri Toplanması ve/veya İşlemesi - D.Ö.Ç.; Analiz ve/veya Yorum - D.Ö.Ç., B.K.; Literatür Taraması - D.Ö.Ç.; Yazıyı Yazan - D.Ö.Ç., B.K.; Eleştirel İnceleme - B.K.

Teşekkür: Yazarlar, bu çalışmayı destekleyen Niğde Ömer Halisdemir Üniversitesi Bilimsel Araştırma Projeleri Birimi'ne teşekkür eder.

Çıkar Çatışması: Yazarlar çıkar çatışması bildirmemişlerdir.

Finansal Destek: Bu çalışma Dilek Özmutlu Çakmak (önceki soyadı Öztürk)'ın Yüksek Lisans tezinden özetlenmiştir. Bu çalışma Niğde Ömer Halisdemir Üniversitesi Bilimsel Araştırma Projeleri Koordinasyon Birimince desteklenmiştir.

\section{REFERENCES}

1. Dubey JP, Beattie CP. Toxoplasmosis of Animals and Man. Inc Boca Raton Florida, CRC Press; 1988.

2. Levine ND. Veterinary Protozoology. Ames, lowa State University Press; 1985.

3. Schmidt DG, Roberts LS. Foundations of Parasitology. Missouri, Times Mirror/Mosby College Publishing; 1989

4. Soulsby EJL. Helminths, Arthropods and Protozoa of Domesticated Animals. Seventh Edition, England, Bailliere Tindall; 1986.

5. Dubey JP. Toxoplasmosis. JAVMA 1994; 205: 1593-8.

6. Dubey JP. Advances in the life cycle of Toxoplasma gondii. Intl J Parasitol 1998; 28: 1019-24. [CrossRef]

7. Aktas M, Dumanlı N, Babur C, Karaer Z, Ongor H. Determination of Seropositivity for Toxoplasma gondii Infection in Pregnant and Aborted Sheep in Elazig and Vicinity by Sabin-Feldman (SF) Test. Turk J Vet Anim Sci 2000; 24: 239-41.

8. Altıntas K. Abort yapan ve yapmayan koyunlara ait fotuslerle gebe olmayan koyunlarda Toxoplasma enfeksiyonu yonunden arastırmalar. Doktora Tezi, Ankara: Ankara Universitesi Veteriner Fakültesi. 1975.

9. Babur C, Karaer Z, Cakmak A, Yaralı C, Zeybek H. Ankara yöresinde Sabin-Feldman (SF), Indirekt Floresan Antikor (IFA), Latex Aglutinasyon (LA) testleri ile koyun toxoplasmosis'inin prevalansı. FÜ Sağlık Bil Derg 1996; 10: 273-7.

10. Babur C, Inci A. Karaer Z. Detection on seropositivitiy of Toxoplasma gondii in sheep and goats in around of Çankırı using Sabin-Feldman Dye test. Türkiye Parazitol Derg 1997; 21: 409-12.

11. Cicek H, Babur C, Karaer Z. Seroprevalence of Toxoplasma gondii in sheep using Sabin-Feldman (SF) dye test in Afyon province. AÜ Vet Fak Derg 2004; 51: 229-31.

12. Dumanlı N, Guler S, Koroglu E, Orak S. Elazığ yöresinde koyunlarda Toxoplasma gondii'nin yayılışı. Doğa Tr Vet Anim Sci 1991; 16: 10-8.

13. Ekmen H. Toxoplasmozis'te enfeksiyon kaynakları. 1-Koyun ve sığırlarda Toxoplasma antikorları. Mikrobiyol Bült 1967; 1: 243-8.

14. Mor N, Arslan MÖ. Seroprevalence of Toxoplasma gondii in Sheep in Kars Province. Kafkas Üniv Vet Fak Derg 2007; 13: 165-70. [CrossRef]

15. Sevgili M, Babur C, Nalbantoglu S, Karas G, Vatansever Z. Determination of seropositivity for Toxoplasma gondii in sheep in Şanlıurfa province. Turk J Vet Anim Sci 2005; 29: 107-11.

16. Arda M, Bisping W, Aydin N, Istanbulluoglu E, Akay O, Izgur M, et al. An etiologic and serologic investigation of ovine abortions in Central Anatolia Region. Ankara Üniv Vet Fak Derg 1987; 34: 195-206.

17. Zeybek H, Yaralı C, Nishikawa H, Nishikawa F, Dundar B. Ankara yöresi koyunlarında Toxoplasma gondii'nin prevalansının saptanması. Etlik Vet Mikrob Derg 1995; 8: 80-6.

18. Oz I, Ozyer M, Corak M. Adana yöresi sığır, koyun ve keçilerinde ELISA ve IHA testleri ile toxoplasmosisin yaygınlığının araştırılması. Etlik Vet Mikrob Derg 1995; 8: 87-99.
19. Babur C, Esen B, Bıyıkoglu G. Seroprevalence of Toxoplasmosis gondii in Sheep in Yozgat, Turkey. Turk J Vet Anim Sci 2001; 25: 2835.

20. Karatepe M, Babur C, Karatepe B. Seroprevalence of Toxoplasma gondii detected by the Sabin-Feldman Dye Test in sheep in teh region of Gümüşhacıköy (Amasya). Türkiye Parazitol Derg 2001; 25: 110-112.

21. Karatepe B, Babur C, Karatepe M, Cakmak A, Nalbantoglu S. Seroprevalance of toxoplasmosis in sheep and goats in the Nigde province of Turkey. Indian Vet J 2004; 81: 974-6.

22. Ozturk C, Babur C, Aslan G. Mersin yöresinde koyunlarda ve mezbaha çalışanlarında Sabin-Feldman boya testi ile anti-Toxoplasma gondii antikorlarının araştırılması. Genel Tıp Derg 2002; 12: 21-4.

23. Yıldız K, Babur C, Kılıc S, Aydenizoz M, Dalkılıc I. Investigation of anti-Toxoplasma antibodies in slaughtered sheep and cattle as well as in workers in the abattoir of Kırıkkale. Türkiye Parazitol Derg 2000; 24: 180-5.

24. Akoz M, Aydın I, Kamburgil K, Handemir E. Determination of Toxoplasma gondii Seroprevalence by Indirect Fluorescent Antibody (IFA) Test in Abortion Experienced and Abortion Inexperienced Sheep in Karapınar District of Konya. Vet Bil Derg 2009; 25: 37-43.

25. Sevinc F, Kamburgil K, Dik B, Guclu F, Aytekin H. The Seroprevalence of Toxoplasmosis by Indirect Fluorescent Antibody (IFA) Test in Ewes with and without Abortion in Konya Province. FÜ Sağlık Bil Derg 2000; 14: 137-42

26. O'Donoghue PJ, Riley MJ, Clarke JF. Serological survey for Toxoplasma infections in sheep. Aust Vet J 1987; 64: 40-5. [CrossRef]

27. Dubey JP, Kırkbride CA. Enzootic toxoplasmosis in sheep in north-central United States. J Parasitol 1989; 75: 673-76. [CrossRef]

28. Savio E, Nietro A. Ovine toxoplasmosis: Seroconversion during pregnancy and lamb birth rate in Uruguayan sheep flocks. Vet Parasitol 1995; 60: 241-7. [CrossRef]

29. Zaki M. Seroprevalence of Toxoplasma gondii in domestic animals in Pakistan. J Pak Med Assoc 1995; 45: 4-5.

30. Hashemi-Fesharki R. Seroprevalence of Toxoplasma gondii in cattle, sheep and goats in Iran. Vet Parasitol 1996; 61: 1-3. [CrossRef]

31. Gorman T, Arancibia JP, Lorca M, Hird D, Alcaino H. Seroprevalence of Toxoplasma gondii infection in sheep and alpacas (Llama pacos) in Chile. Prev Vet Med 1999; 40: 143-9. [CrossRef]

32. Pita Gondim LF, Barbosa Jr HV, Ribeiro Filho CHA, Saeki H. Serological survey of antibodies to Toxoplasma gondii in goats, sheep, cattle and water buffaloes in Bahia State, Brazil. Vet Parasitol 1999; 82: 273-6. [CrossRef]

33. Dubey JP, Foreyt WJ. Seroprevalence of Toxoplasma gondii in Rocky Mountain Bighorn Sheep (Ovis canadensis). J Parasitol 2000; 86: 622-3. [CrossRef]

34. El-Moukdad AR. Serological studies on prevalence of Toxoplasma gondii in Awassi sheep in Syria. Berl Munch Tierarztl Wochenschr 2002; 115: 186-8.

35. Masala G, Porcu R, Madau L, Tanda A, Ibba B, Satta G, et al. Survey of ovine and caprine toxoplasmosis by IFAT and PCR assays in Sardinia, Italy. Vet Parasitol 2003; 117: 15-21. [CrossRef]

36. Sawadogo P, Hafid J, Bellete B, Tran Manh Sung R, Chakdi M, Flori P, et al. Seroprevalence of T. gondii in sheep from Marrakech, Morocco. Vet Parasitol 2005; 130: 89-92. [CrossRef]

37. Asgari $Q$, Mehrabani D, Moazzeni M, Akrami-Mohajeri F, Kalantari $\mathrm{M}$, Motazedian $\mathrm{MH}$, et al. The seroprevalence of ovine toxoplasmosis in Fars province, Southern Iran. Asian J Anim Vet Adv 2009; 4: 332-6. [CrossRef]

38. Lashari MH, Tasawar Z. Seroprevalence of toxoplasmosis in sheep in southern Punjab, Pakistan. Pak Vet J 2010; 30: 91-4. 